\title{
Sensitivity of hyperparasitic fungi to alternative products for use in the control of papaya black spot
}

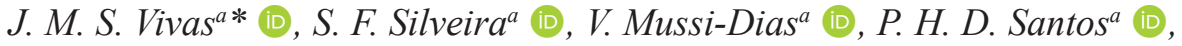 \\ G. K. S. Ramos ${ }^{b}$ (D), P. R. Santos ${ }^{b}$ (D) and R. N. Almeida \\ a Laboratório de Entomologia e Fitopatologia - LEF, Centro de Ciências e Tecnologias Agropecuárias - CCTA, \\ Universidade Estadual do Norte Fluminense Darcy Ribeiro - UENF, Av. Alberto Lamego, 2000, Parque Califórnia, \\ CEP 28013-602, Campos dos Goytacazes, RJ, Brasil \\ 'Laboratório de Engenharia Agrícola - LEAG, Centro de Ciências e Tecnologias Agropecuárias - CCTA, \\ Universidade Estadual do Norte Fluminense Darcy Ribeiro - UENF, Av. Alberto Lamego, 2000, Parque Califórnia, \\ CEP 28013-602, Campos dos Goytacazes, RJ, Brasil \\ *e-mail: Janielims19@yahoo.com.br
}

Received: October 2, 2018 - Accepted: September 5, 2019 - Distributed: February 28, 2021 (With 2 figures)

\begin{abstract}
The use of more than one control technique can maximize the reduction of the damages caused by the fungus Asperisporium caricae causal agent of the black spot in the papaya crop. The objective of this work was to evaluate the sensitivity of the fungi Hansfordia pulvinata and Acremonium spp. to alternative products with potential for use in the control of the black-spotted ptarmigan. Three isolates of Acremonium spp. (A-598, A-602 and A-617) and an isolate of H. pulvinata (H-611) were grown in BDA medium containing Agro-Mos ${ }^{\circledR}$, Bion ${ }^{\circledR}$, Ecolife ${ }^{\circledR}$, Hortifospk $^{\circledR}$, Matriz $\mathrm{G}^{\circledR}$, Vitaphol ${ }^{\circledR}$ separately. The Amistar $500 \mathrm{WG}{ }^{\circledR}$ fungicide was used as a positive control and pure BDA as a negative control. The toxicity of the tested products was determined based on the values of the biological index, derived from the means of mycelial growth, sporulation and germination of conidia, in each experimental unit. In this way it was possible to select the products classified as compatible for all isolates, and to test them in vivo. In the greenhouse, only the isolates and isolates with selected products, were applied in papaya plants with foliar symptoms of black-spotted. The incidence of leaves with hyperparasites and the percentage of black-painted lesions colonized by the tested isolates were evaluated. Thus, the H-611 isolate proved to be compatible with most of the alternative products tested, except with Hortifos ${ }^{\circledR}$. Bion ${ }^{\circledR}$ and Matrix ${ }^{\circledR}$ products were compatible with all tested isolates and could be used in conjunction with Acremonium spp. and H. pulvinata to control the papaya black spot, since these products did not present toxicity on the hyperparasitic fungi.
\end{abstract}

Keywords: compatibility, toxicity, Acremonium spp., Hansfordia pulvinata.

\section{Sensibilidade de fungos hiperparasitas a produtos alternativos para uso no controle da pinta preta do mamoeiro}

\section{Resumo}

O uso de mais de uma técnica de controle pode maximizar a redução dos danos causados pelo fungo Asperisporium caricae agente causal da pinta preta na cultura do mamoeiro. O objetivo deste trabalho foi avaliar a sensibilidade dos fungos Hansfordia pulvinata e Acremonium spp. a produtos alternativos com potencial para uso no controle da pinta-preta. Três isolados de Acremonium spp. (A-598, A-602 e A-617) e um isolado de H. pulvinata (H-611) foram

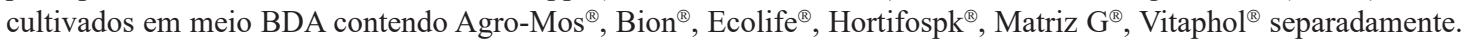
Fungicida Amistar $500 \mathrm{WG}^{\circledR}$ foi utilizado como controle positivo e BDA puro, como controle negativo. A toxicidade dos produtos testados foi determinada com base nos valores do índice biológico, provenientes das médias do crescimento micelial, esporulação e germinação de conídios, em cada unidade experimental. Dessa forma foi possível selecionar os produtos classificados como compatíveis para todos os isolados, e testá-los in vivo. Em casa de vegetação, somente os isolados e os isolados com produtos selecionados, foram aplicados em plantas de mamoeiro com sintomas foliares de pinta-preta. Avaliaram-se a incidência de folhas com hiperparasitas e a porcentagem de lesões de pinta-preta colonizadas pelos isolados testados. Assim o isolado H-611 mostrou-se compatível com a maioria dos produtos alternativos testados, exceto com Hortifos ${ }^{\circledR}$. Os produtos Bion ${ }^{\circledR}$ e Matriz ${ }^{\circledR}$ apresentaram compatibilidade com todos os isolados testados, podendo ser utilizados em conjunto com o Acremonium spp. e H. pulvinata para controlar a pinta-preta do mamoeiro, uma vez que estes produtos não apresentaram toxidade sobre os fungos hiperparasitas.

Palavras-chave: compatibilidade, toxicidade, Acremonium spp., Hansfordia pulvinata. 


\section{Introduction}

The development of sustainable measures to control plant diseases presents alternatives to reduce the dependence on pesticides, contribute to preserving the environment and, consequently, improve life quality in rural areas. One of the techniques that fit in this context is the integrated management of diseases based on a series of foundations and tools. This technique aims to economically optimize disease control through the consistent use of tactics that maintain production reduction below the threshold of economic damage (Bergamin Filho, 2008). However, its purpose is to achieve its effectiveness without damaging man, animals, plants, and the environment.

In papaya crop, the black spot disease, caused by the Asperisporium caricae (Speg.) Maubl., characterized by being harmful, reducing the active leaf area of the plant, also depreciating the commercial aspect of the product (Ventura and Rezende, 2016), thus requiring many applications of fungicides to control it (Barreto et al., 2011). Besides fungicide applications, some measures are recommended to control black spot, such as the removal of diseased leaves from the orchard to reduce the inoculum of the fruit (Suzuki et al., 2007) and the monitoring of the disease to minimize pesticide applications (Ventura and Rezende, 2016).

However, studies in search of integrated control strategies for papaya black spot are scarce (Santos and Barreto, 2003). According to Martelleto et al. (2009), the difficulty in controlling the papaya black spot is most evident in the organic production system due to few research results and to restriction on conventional fungicide use. To contribute to the alternative control for this disease, the application of phosphite, foliar fertilizers, and resistance inductors has been studied (Pratissoli et al., 2007; Oliveira and Nishijima, 2014; Santos et al., 2017). Oliveira and Nishijima (2014) concluded that the acibenzolar-S-methyl product induces partial resistance to the papaya against black spot; thus, it may be an option for the control of the disease. Nevertheless, it is believed that the disease control may increase when using more than one control technique.

The biological control is, in turn, a possibility that has been studied for papaya trees (Vivas et al., 2015, 2017, 2018). This measure consists of using an antagonistic organism, which reduces the multiplication or survival of the pathogen, resulting in the control of the disease. It has been reported the hyperparasitic fungi Hansfordia pulvinata (Berk. \& M.A Curtis) S. Hugles and Acremonium Link species as having the potential to control the black spot in the papaya crop (Vivas et al., 2017). The biological control is a common strategy applied to agroecological systems, as well as to conventional agriculture, which uses the integrated pest and disease management. It is thought that combining this control measure with alternative products could reduce the population of pathogens below the economic damage threshold, once alternative products would hinder, delay, or both actions the new lesions, while the hyperparasitic fungi would act in lesions already established, reducing the inoculum production and the survival of the pathogen in the lesions.

Nonetheless, studies are needed to evaluate the compatibility between the biological control and the use of alternative products, since such products may be toxic to the hyperparasitic fungi, compromising their action to control diseases. Therefore, the objective of this work was to evaluate the sensitivity of the isolates of $H$. pulvinata and Acremonium spp. fungi to alternative products with potential for use in the control of papaya black spot.

\section{Material and Methods}

\subsection{Hyperparasites and alternative products used}

Three isolates of Acremonium (A-598, A-602, and A-617) and one of $H$. pulvinata (H-611), previously obtained by direct isolation from lesions of papaya black spot with signs of hyperparasites were used (Vivas et al., 2015). The monosporic cultures were preserved in tubes, under refrigeration at $10^{\circ} \mathrm{C}$, transferred to Petri dishes containing PDA, and placed in BOD incubator at $25 \pm 0.5^{\circ} \mathrm{C}$, under a 12-hour photoperiod for 12 days.

To determine the compatibility of the hyperparasites to alternative products with potential for use in the papaya crop, the following products were tested: Agro-Mos ${ }^{\circledR}$, Bion $^{\circledR}$, Ecolife ${ }^{\circledR}$, Hortifospk ${ }^{\circledR}$, Matriz $^{\circledR}{ }^{\circledR}$, and Vitaphol ${ }^{\circledR}$. A fungicide Amistar $500 \mathrm{WG}^{\circledR}$ was used as positive control and only the hyperparasitic fungi as a negative control (Table 1). The isolates and the products were

Table 1. Products used to evaluate sensitivity in hyperparasitic fungi of the papaya black spot.

\begin{tabular}{|c|c|c|}
\hline Trade Name & Active Ingredients & Dosage/L* \\
\hline AGRO-MOS $^{\circledR}$ & Phosphorylated mannanoligosaccharide, Copper Sulphate, Zinc Sulphate & $2 \mathrm{~mL}$ \\
\hline $\mathrm{BION}^{\circledR}$ & Acibenzolar-S-Methyl & $0.06 \mathrm{~g}$ \\
\hline ECOLIFE $^{\circledR}$ & Bioflavonoids, Ascorbic Acid, Lactic Acid, and vegetable glycerin & $2 \mathrm{~mL}$ \\
\hline HORTIFOS PK ${ }^{\circledR}$ & Potassium Phosphite $\left(\mathrm{P}_{2} \mathrm{O}_{5} 28 \%\right.$ and $\left.\mathrm{K}_{2} \mathrm{O} ; 26 \%\right)$ & $2 \mathrm{~mL}$ \\
\hline MATRIZ G ${ }^{\circledR}$ & $\begin{array}{l}\text { Phosphorus }\left(\mathrm{P}_{2} \mathrm{O}_{5}\right) 3.00 \% \mathrm{pp} \text {, Nitrogen }(\mathrm{N}) 1.00 \% \mathrm{pp} \text {, Potassium }(\mathrm{K} 2 \mathrm{O}) 2.00 \% \mathrm{pp} \text {, } \\
\text { Sulphur }(\mathrm{S}) 2.47 \% \text { pp,Magnesium }(\mathrm{Mg}) 1.00 \% \mathrm{pp} \text {, Boron }(\mathrm{B}) 0.50 \% \mathrm{pp} \text {, } \\
\text { Manganese }(\mathrm{Mn}) 0.50 \% \mathrm{pp} \text {, Zinc }(\mathrm{Zn}) 0.10 \% \mathrm{pp} \text {, Carbon }(\mathrm{C}) 6.00 \% \mathrm{pp} \text {, } \\
\text { Fulvicacids } 12.00 \% \mathrm{pp}\end{array}$ & $1 \mathrm{~mL}$ \\
\hline VITAPHOL ${ }^{\circledR}$ & Phosphorus $6.0 \%$, Potassium $15.0 \%$, Silicon $5.0 \%$ & $2 \mathrm{~mL}$ \\
\hline AMISTAR 500WG ${ }^{\circledR}$ & Azoxystrobin & $0.16 \mathrm{~g}$ \\
\hline CONTROL & Distilled and sterile water & \\
\hline
\end{tabular}

*Dose recommended by the manufacturer for control of foliar diseases. 
utilized to conduct tests in vitro, under greenhouse conditions or both.

\subsection{Effect of different products on mycelial growth, sporulation, and conidial viability}

The experiments (one for each isolate) were conducted in a randomized block design with four replicates. After preparing the PDA culture medium, the products presented in Table 1 were directly added to the culture medium, when it was still melting, by manual agitation until the products were completely diluted. The culture medium containing the products was poured into Petri dishes (approximately $20 \mathrm{~mL}$ per dish). After the culture medium had been solidified, the fungi were transferred $(7 \mathrm{~mm}$ discs from the median portion of the monosporic colony of the $\mathrm{BDA}$ isolates) to the Petri dish centre. The incubation in BOD was carried out at $25 \pm 0.5^{\circ} \mathrm{C}$, under a 12-hour photoperiod for 15 days.

The mycelial growth was measured, with a transparent ruler, on the external part on the bottom of the dish, after 15 days of incubation, when the radial growth of the colonies was measured in two orthogonal directions to, then, obtain the mean of both measures. Discs with 7-mm diameter were removed from the median area of the colonies using a cork punch to evaluate the sporulation, according to the methodology described by Vivas et al. (2015). The discs were transferred to an assay tube containing $1 \mathrm{~mL}$ of water with $0.3 \%$ of Tween at $20 \%$. After agitating the suspension in a tube stirrer for 1 minute, it was removed with a pipette, and the spores were counted in Neubauer chamber.

A second experiment was conducted to evaluate the viability of the conidiain the presence of the products. This work is a microcultivation test and direct examination in a slide on a light microscope in a randomized block design with four replicates. For this purpose, five discs of $7 \mathrm{~mm}$ removed from the PDA Petri dishes with different alternative products (Table 1) were placed on sterilized glass slides. Subsequently, an aliquot of $0.5 \mathrm{~mL}$ of a fungal suspension of $1 \times 10^{4}$ conidiamL ${ }^{-1}$ was placed on the discs. The slides with the discs were placed in Gerbox and a humid piece of cotton wool (humid chamber) and kept in BOD at $25 \pm 0.5^{\circ} \mathrm{C}$ for 12 hours, in the light. After this period, germination of the conidia was stopped with the addition of $20 \mu \mathrm{L}$ of lactophenol. The slides were placed under an optical microscope and 80 conidia per disc were sampled in three visual fields, at a magnification of 200x. The number of conidia germinated (those with germ tube equal to or larger than one conidia) and the number of conidia non-germinated were counted. Next, a proportion of conidia germinated was established.

The experiments were repeated once, and the values of mycelial growth, sporulation, and conidial germination of each isolate were subjected to analysis of variance, considering the analysis of groups of experiments. The means of each product for each isolate were compared by the Tukey test $(p<0.05)$. The analyses were carried out by the Genes program (Cruz, 2013).
The compatibility between products and fungi was based on the calculation of toxicity proposed by Rossi-Zalaf et al. (2008), applying mycelial growth, sporulation of the fungus, and conidial viability variables. The following expression was used: $B I=(47 M G+43 S P+10 C G) / 100$, being, $\mathrm{BI}=$ biological index; $\mathrm{MG}=$ percentage of mycelial growth of the colony after 15 days in relation to the control treatment; $\mathrm{SP}=$ percentage of sporulation after 15 days relating to the control treatment; $\mathrm{CG}=$ percentage of conidial germination after 15 hours regarding the control treatment. According to the values of the estimates obtained for the biological index (BI), the toxicity of each product to the fungi tested was classified as Toxic $(0<\mathrm{IB}<41)$; Moderately toxic $(42<\mathrm{IB}<66)$, and Compatible (IB $>66)$.

\subsection{Effect of alternative products on hyperparasite fungi colonization under papaya black spot lesions at greenhouse conditions}

To assess whether the alternative products would interfere with the hyperparasitism in lesions of papaya black spot, it was conducted, under greenhouse (screen shade 50\%), an experiment in a randomized block design with three repetitions. The experimental plot consisted of a pot of $5 \mathrm{~L}$ with a plant of papaya cv. Golden with approximately 180 days after planting presenting typical symptoms and signs of black spot. That experiment was repeated once, in both experiments, plants with no presence of hyperparasite were used, and with a similar amount of black-spot severity $(2.32 \%$ in the first and $2.37 \%$ in the second experiment).

The hyperparasitic isolates used in this study were one of $H$. pulvinata and three of Acremonium sp. cultivated in autoclaved rice medium, kept in BOD at $25 \pm 0.5^{\circ} \mathrm{C}$ for 15 days with photoperiod for 12 hours. The products applied were the ones classified as being compatible with the four fungi tested in vitro $\left(\right.$ Bion $^{\circledR}$ and Matriz $\left.\mathrm{G}^{\circledR}\right)$. With the help of a manual sprayer, $20 \mathrm{~mL}$ of each product together with $3 \times 10^{4}$ conidia $\mathrm{mL}^{-1}$ of hyperparasitic fungi were sprayed. Suspension of $3 \times 10^{4}$ conidia $\mathrm{mL}^{-1}$ of the fungi suspended in sterile distilled water was sprayed in the control treatment. Aiming to control the natural occurrence of hyperparasitic fungi, papaya plant showing symptoms and signs typical of the black spott were sprayed only with water. These pulverizations occurred every 15 days during a two-month period.

The number of leaves with black spot symptoms as well as the number of leaves with black spot symptoms and hyperparasitic signs were weekly quantified throughout two months. The incidence of leaves with symptoms of the hyperparasitic black spot was obtained from this information by calculating the ratio of the number of leaves with hyperparasitic black spot symptoms by the number of leaves with black spot symptoms, multiplied by 100 .

In addition to the incidence, it was evaluated the severity of black spot in leaf and the severity of hyperparasitic black spot, being this one visually estimated from the last viable leaf, with a diagrammatic scale adopted by Vivas et al. (2011). Subsequently, the percentage of the 
hyperparasitic black spot was calculated by the ratio of the severity of hyperparasitic lesions by the severity of total black spot, multiplied by 100 .

The percentage and incidence values for a hyperparasitic black spot (severity) were converted into the area under disease progress curve (AUDPC), according to Campbell and Madden (1990). The values were submitted to analysis of variance, considering the analysis of groups of experiments. The means of each product for each isolate were compared by the Tukey test $(p<0.05)$. The analyses were carried out by the Genes program (Cruz, 2013).

\section{Results and Discussion}

\subsection{Sensitivity in vitro of Acremonium spp. and}

H. pulvinata to products for use in the alternative control of black spot

In the analysis of variance conducted for each isolate, it was noticed the significance of the variation source treatment for the three variables under study (mycelial growth, sporulation, and conidial germination). It was also seen that the source of variation products versus experiments was not significant. From the results obtained, it is observed that products act differently on the fungus, and the results obtained are similar in both experiments conducted.

When analyzing the variables on the growing medium considered as control (PDA), differences in the magnitudes of mycelial growth, sporulation, and conidial germination were observed both in (Acremonium spp. and H. pulvinata) and in gender (Acremonium spp.). Thus, the sporulation was abundant for the A- 602 isolate $\left(6.92 \times 10^{7}\right.$ conidia. $\left.\mathrm{mL}^{-1}\right)$ when compared to the other isolates (Table 2). That is because of the difference in genders, although it may even occur in the same lineage of fungi. The natural genetic variability between isolates of the same species of fungus is well known and widely reported in the literature for several biological parameters, including for sensitivity to synthetic chemical products (Liu et al., 1993; Anhalt et al., 2010).

The means of the variables assessed in the isolates cultivated in dishes containing the Amistar $500 \mathrm{WG}^{\circledR}$

Table 2. Biological index and classification of the resistance inductors regarding the toxicity of hyperparasitic fungi of the papaya black spot in a culture medium.

\begin{tabular}{|c|c|c|c|c|c|}
\hline Products Tested & $\begin{array}{c}\text { Mycelial } \\
\text { Growth }(\mathrm{cm})\end{array}$ & $\begin{array}{c}\text { Sporulation } \\
\left(10^{4} \text { Conidia } / \mathrm{mL}\right) \\
\end{array}$ & $\begin{array}{c}\text { Germination } \\
(\%) \\
\end{array}$ & $\begin{array}{l}\text { Biological } \\
\text { Index (\%) }\end{array}$ & $\begin{array}{l}\text { Toxicological } \\
\text { Classification }^{\mathrm{a}} \\
\end{array}$ \\
\hline \multicolumn{6}{|c|}{ Isolate A-617 (Acremonium spp.) } \\
\hline Amistar ${ }^{\circledR}$ & $0.95 \mathrm{~d}^{*}$ & $262.50 \mathrm{~b}$ & $0.89 \mathrm{e}$ & 19 & $\mathrm{~T}$ \\
\hline Control & $3.08 \mathrm{ab}$ & $2618.75 \mathrm{a}$ & $100.00 \mathrm{a}$ & 100 & $\mathrm{C}$ \\
\hline Agro-Mos $^{\circledR}$ & $1.37 \mathrm{~d}$ & $23.08 \mathrm{c}$ & $82.44 \mathrm{~cd}$ & 30 & $\mathrm{~T}$ \\
\hline Hortifos $^{\circledR}$ & $2.13 \mathrm{c}$ & $64.06 \mathrm{bc}$ & $88.95 \mathrm{bc}$ & 43 & MT \\
\hline Bion $^{\circledR}$ & $2.82 \mathrm{~b}$ & $2951.04 \mathrm{a}$ & $91.90 \mathrm{~b}$ & 95 & $\mathrm{C}$ \\
\hline Matriz $^{\circledR}$ & $2.16 \mathrm{c}$ & $1851.56 \mathrm{a}$ & $77.15 \mathrm{~d}$ & 71 & $\mathrm{C}$ \\
\hline Ecolife $^{\circledR}$ & $1.36 \mathrm{~d}$ & $1731.51 \mathrm{a}$ & $0.97 \mathrm{e}$ & 49 & MT \\
\hline Vitaphol $^{\circledR}$ & $3.28 \mathrm{a}$ & $2243.75 \mathrm{a}$ & $95.75 \mathrm{ab}$ & 93 & $\mathrm{C}$ \\
\hline Coefficient of variation (\%) & 8.62 & 12.00 & 4.79 & & \\
\hline \multicolumn{6}{|c|}{ Isolate A-598 (Acremonium spp.) } \\
\hline Amistar $^{\circledR}$ & $1.92 \mathrm{bcd}$ & $1417.97 \mathrm{a}$ & $84.93 \mathrm{~b}$ & 88 & $\mathrm{C}$ \\
\hline Control & $2.49 \mathrm{ab}$ & $1284.90 \mathrm{a}$ & $97.25 \mathrm{a}$ & 100 & $\mathrm{C}$ \\
\hline Agro-Mos ${ }^{\circledR}$ & $0.96 \mathrm{f}$ & $129.17 \mathrm{c}$ & $87.75 \mathrm{~b}$ & 32 & $\mathrm{~T}$ \\
\hline Hortifos $^{\circledR}$ & $1.34 \mathrm{def}$ & $65.24 \mathrm{c}$ & $92.92 \mathrm{ab}$ & 37 & $\mathrm{~T}$ \\
\hline Bion $^{\circledR}$ & 1.83 cde & $1086.46 \mathrm{ab}$ & $91.09 \mathrm{ab}$ & 80 & $\mathrm{C}$ \\
\hline Matriz $^{\circledR}$ & $1.98 \mathrm{bc}$ & $764.06 \mathrm{ab}$ & $92.61 \mathrm{ab}$ & 72 & $\mathrm{C}$ \\
\hline Ecolife $^{\circledR}$ & $1.30 \mathrm{ef}$ & $262.27 \mathrm{bc}$ & $0.33 \mathrm{c}$ & 33 & $\mathrm{~T}$ \\
\hline Vitaphol $^{\circledR}$ & $2.58 \mathrm{a}$ & $287.50 \mathrm{bc}$ & $93.99 \mathrm{ab}$ & 66 & MT \\
\hline Coefficient of variation (\%) & 14.62 & 14.42 & 5.35 & & \\
\hline \multicolumn{6}{|c|}{ Isolate A-602 (Acremonium spp.) } \\
\hline Amistar $^{\circledR}$ & $1.22 \mathrm{c}$ & $868.75 \mathrm{~b}$ & $0.17 \mathrm{c}$ & 26 & $\mathrm{~T}$ \\
\hline Control & $2.77 \mathrm{ab}$ & $6925.00 \mathrm{a}$ & $92.96 \mathrm{ab}$ & 100 & $\mathrm{C}$ \\
\hline Agro-Mos $^{\circledR}$ & $1.15 \mathrm{c}$ & $103.91 \mathrm{c}$ & $90.55 \mathrm{ab}$ & 30 & $\mathrm{~T}$ \\
\hline Hortifos $^{\circledR}$ & $1.24 \mathrm{c}$ & $51.56 \mathrm{c}$ & $95.95 \mathrm{ab}$ & 31 & $\mathrm{~T}$ \\
\hline Bion $^{\circledR}$ & $2.50 \mathrm{ab}$ & $8150.00 \mathrm{a}$ & $89.65 \mathrm{~b}$ & 95 & $\mathrm{C}$ \\
\hline Matriz $^{\circledR}$ & $2.25 \mathrm{~b}$ & $7198.96 \mathrm{a}$ & $96.34 \mathrm{a}$ & 91 & $\mathrm{C}$ \\
\hline Ecolife $^{\circledR}$ & $1.22 \mathrm{c}$ & $2026.56 \mathrm{ab}$ & $1.49 \mathrm{c}$ & 33 & $\mathrm{~T}$ \\
\hline
\end{tabular}

aToxicological classification: $\mathrm{C}=$ Compatible; $\mathrm{MT}=$ Moderately Toxic; and, $\mathrm{T}=$ Toxic; $*$ For each one, the means of products followed by the same letter do not differ by the Tukey test $(\mathrm{p}<0.05)$. 
Table 2. Continued...

\begin{tabular}{|c|c|c|c|c|c|}
\hline Products Tested & $\begin{array}{c}\text { Mycelial } \\
\text { Growth (cm) }\end{array}$ & $\begin{array}{c}\text { Sporulation } \\
\left(10^{4} \text { Conidia } / \mathrm{mL}\right)\end{array}$ & $\begin{array}{c}\text { Germination } \\
(\%)\end{array}$ & $\begin{array}{l}\text { Biological } \\
\text { Index }(\%)\end{array}$ & $\begin{array}{l}\text { Toxicological } \\
\text { Classification }^{\mathrm{a}}\end{array}$ \\
\hline Vitaphol $^{\circledR}$ & $2.84 \mathrm{a}$ & $840.63 \mathrm{~b}$ & $96.56 \mathrm{a}$ & 62 & MT \\
\hline Coefficient of variation $(\%)$ & 12.79 & 9.85 & 4.17 & & \\
\hline \multicolumn{6}{|l|}{ Isolate H-611 (H. pulvinata) } \\
\hline Amistar ${ }^{\circledR}$ & $0.90 \mathrm{c}$ & $370.83 \mathrm{ab}$ & $4.55 \mathrm{c}$ & 53 & MT \\
\hline Control & $2.50 \mathrm{a}$ & $442.97 \mathrm{a}$ & $98.15 \mathrm{a}$ & 100 & $\mathrm{C}$ \\
\hline Agro-Mos ${ }^{\circledR}$ & $2.06 \mathrm{ab}$ & $291.15 \mathrm{ab}$ & $79.89 \mathrm{~b}$ & 75 & $\mathrm{C}$ \\
\hline Hortifos $^{\circledR}$ & $1.04 \mathrm{c}$ & $207.03 \mathrm{~b}$ & $95.69 \mathrm{a}$ & 49 & MT \\
\hline Bion $^{\circledR}$ & $2.34 \mathrm{ab}$ & $414.06 \mathrm{a}$ & $94.27 \mathrm{a}$ & 94 & $\mathrm{C}$ \\
\hline Matriz $^{\circledR}$ & $2.43 \mathrm{a}$ & $583.59 \mathrm{a}$ & $95.07 \mathrm{a}$ & 98 & $\mathrm{C}$ \\
\hline Ecolife $^{\circledR}$ & $1.82 \mathrm{~b}$ & $419.79 \mathrm{a}$ & $95.22 \mathrm{a}$ & 85 & $\mathrm{C}$ \\
\hline Vitaphol $^{\circledR}$ & $2.35 \mathrm{ab}$ & $476.56 \mathrm{a}$ & $91.55 \mathrm{a}$ & 97 & $\mathrm{C}$ \\
\hline Coefficient of variation $(\%)$ & 12.27 & 5.67 & 5.36 & & \\
\hline
\end{tabular}

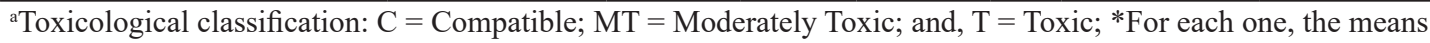
of products followed by the same letter do not differ by the Tukey test $(p<0.05)$.

fungicide, made from azoxystrobin, presented the lowest magnitudes, mainly on the A-617, A-602, and $\mathrm{H}-611$ isolates (Table 2), significantly reducing both the mycelial growth $(0.95,1.22$ and $0.90 \mathrm{~cm}$, for the A-617, A-602, and H-611 isolates, respectively) and the sporulation (2.62, 8.69 and $3.71 \times 10^{6}$ conidia. $\mathrm{mL}^{-1}$, for the A-617, A-602, and $\mathrm{H}-611$ isolates, respectively). The Amistar $500 \mathrm{WG}^{\circledR}$ fungicide belongs to the strobilurin group. These compounds act by hindering the biochemical chain of electron transfer in the mitochondrial plot, interfering with the respiration of the pathogen (Ghini and Kimati, 2000) resulting in death, and becoming toxic to fungi. As noted, the fungicide was classified as toxic (A-617 and A-602) or moderately toxic (H-611). However, that effect was not noticed for the A-598 isolate, for which the Amistar $500 \mathrm{WG}^{\circledR}$ fungicide had a compatible toxicological classification (Table 2). It may indicate a resistance of the fungus to the fungicide applied in papaya crops to control fungal diseases.

Two other products, Agro-Mos ${ }^{\circledR}$ and Ecolife ${ }^{\circledR}$, were categorized as toxic, moderately toxic, or both for the Acremonium spp. isolates (A-617, A-598, and A-602), and compatible for the H-611 isolate of H. pulvinata (Table 2). This result allows inferring that the $H$. pulvinata fungus presents potential to be used together with Agro-Mos ${ }^{\circledR}$ and Ecolife ${ }^{\circledR}$ to control papaya black spot, as the H-611 isolate showed the largest magnitudes of mycelial growth (2.06 cm for Agro-Mos ${ }^{\circledR}$ and $1.82 \mathrm{~cm}$ for Ecolife ${ }^{\circledR}$ ) and sporulation $\left(2.91 \times 10^{6}\right.$ conidia.mL ${ }^{-1}$ for Agro-Mos ${ }^{\circledR}$ and $\left.4.20 \times 10^{6}{\text { conidia. } \mathrm{mL}^{-1} \text { for Ecolife }}^{\circledR}\right)$ when compared to the other isolates (Table 2). On the other hand, these products were not compatible with the Acremonium spp. isolates. Therefore, the use of Agro-Mos ${ }^{\circledR}$ and Ecolife ${ }^{\circledR}$ together with the biological control becomes limited.

Agro-Mos ${ }^{\circledR}$ is a product based on phosphorylated mannanoligosaccharide, derived from the yeast wall Saccharomyces cerevisiae (Desm.) Meven and from a bio-complex of Copper and Zinc, which has been used to protect plants against diseases (Costa et al., 2010). There are reports of toxic effects of this product on different fungi (Costa et al., 2010). Baldrian (2003) reports that the toxic effect of Ago-Mos ${ }^{\circledR}$ can be attributed to the presence of Copper in its composition. The author also states that some metals, such as Copper, are essential for the fungal metabolism; however, they become toxic when in excess. Nevertheless, the levels of toxicity may vary according to the species of microorganism as observed in the Acremonium spp. and H. pulvinata isolates (Table 2).

Similar to Agro-Mos ${ }^{\circledR}$, Ecolife ${ }^{\circledR}$ was only compatible for H. pulvinata. It was noticed, for the other fungi, that the parameters that were most influenced by this product were the mycelial growth and the conidial germination, conversely, the sporulation was not inhibited (Table 2). Thus, there is not a direct relation between the colony size and the number of conidia produced. One reason is that Ecolife ${ }^{\circledR}$ causes a stress in the fungi colony, but not its death, stimulating spore production. These results suggest that Ecolife ${ }^{\circledR}$ has compounds which are biologically active in its constitution are able to act on the fungus. The organic acids (ascorbic, citric, and lactic) and the bioflavonoids give an antioxidant action to Ecolife ${ }^{\circledR}$; together with the peptides, they act as microbiostatic agents, assisting the balance of the microbial flora (Motoyama et al., 2003). Several authors describe, in their researches, the fungistatic capacity of Ecolife ${ }^{\circledR}$ in vitro (Cruz et al., 2011; Gomes et al., 2016). Other authors observed that, for Ecolife $^{\circledR}$, the antimicrobial activity was dose-dependent (Motoyama et al., 2003; Barguil et al., 2005).

Hortifos $^{\circledR}$, made from potassium phosphite, was the least compatible with the isolates tested, with toxicological classification ranging from toxic (A-598 and A-602) to moderately toxic (A-617 and H-611). It was also noted that this product reduced the sporulation and the mycelial growth (Table 2). The result allowed inferring that this product should not be used together with the hyperparasitic fungi. Despite phosphites in the Hortifos $\mathrm{PK}^{\circledR}$ act by activating the defence system of the host plant, they can also behave 
directly inhibiting the fungi development (Blum et al., 2007). The antifungal action of the phosphites against different pathogens was repeatedly reported in works (Blum et al., 2007; Nojosa et al., 2009; King et al., 2010).

Vitaphol ${ }^{\circledR}$, which is also made from potassium phosphite, was classified as compatible for the A-617 and H-611 isolates and moderately toxic for the A-598 and A-602 isolates, acting mainly in the sporulation of these isolates (Table 2). Like Hortifos ${ }^{\circledR}$, its effect on the fungus depends on the concentration and the species under test. When analyzing the toxicological classification of both products, it is noticed that there was a mitigation of toxicity presented in Hortifos ${ }^{\circledR}$ regarding the one reported in Vitaphol ${ }^{\circledR}$, as expected, since the phosphite concentration is higher in the Hortifos ${ }^{\circledR}$. The H-611 isolate was also compatible with Vitaphol ${ }^{\circledR}$, presenting means of mycelial growth $(2.35 \mathrm{~cm})$, sporulation $\left(4.76 \times 10^{6} \mathrm{conidia} . \mathrm{mL}^{-1}\right)$, and percentage of conidial germination $(91.55 \%)$ statistically equal to the ones of the PDA (Table 2), confirming, thus, the potential of the fungus $H$. pulvinata to be used together with different alternative products to control diseases in papaya, especially, black spot.

From the products tested, only Bion ${ }^{\circledR}$ and Matriz $^{\circledR}$ were compatible with all the hyperparasitic isolates by the biological index (Table 2). This indicates the possibility of using more than one control technique: the use of resistance inductors, foliar fertilizers, or both, as well as the use of biological control. In this case, Bion ${ }^{\circledR}$ and Matriz ${ }^{\circledR}$ act in the plant, and the hyperparasitic fungi, in the disease. However, in vivo studies are needed to confirm this compatibility. In this respect, in vitro studies have the advantage of maximizing the exposure of the microorganism to the action of the chemical product.

\section{2. in vivo effect of alternative products on the colonization of hyperparasitic fungi in A. caricae lesions}

In the tests conducted under greenhouse, there was no a significant interaction effect regarding treatments versus experiments, which allowed analyzing the experiment together. There was also an effect of the source of variation treatment, which was, therefore, dismembered in fungus, product and interaction fungus versus product. An analysis and sources of variation revealed a significant interaction effect only for the incidence of leaves with black spot lesions and signs of hyperparasites. This way, for the incidence of leaves with black spot lesions, hyperparasited, it was executed the unfolding of the sums of squares of the interaction and of their results, to study the effect of the isolate in the fungus and the effect of fungus in each isolate. For the severity of black spot lesions in leaves with signs of hyperparasites, the effect of fungus based on the means of products was analyzed, as well as the effect of products based on the mean of fungi.

It could be seen that the application of the isolates together with the products tested is possible and that the H-661 isolate had the highest magnitudes of the mean leaf incidence with black spot lesions that were hyperparasited (Figure 1A). This isolate was also pointed
A

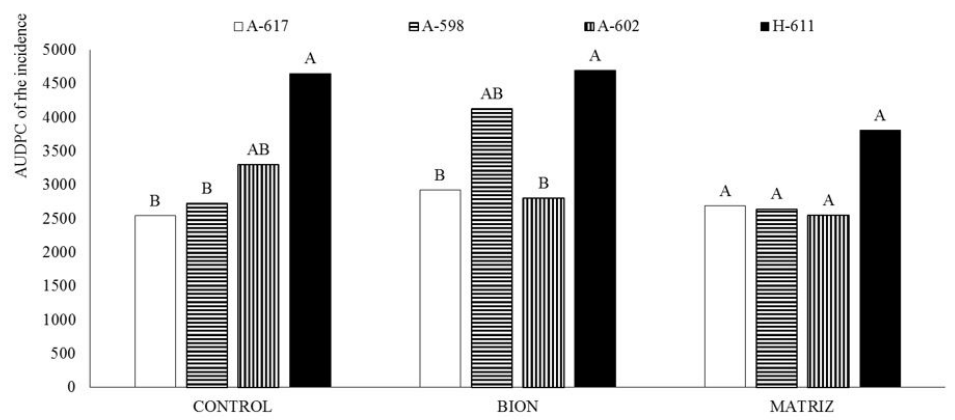

B

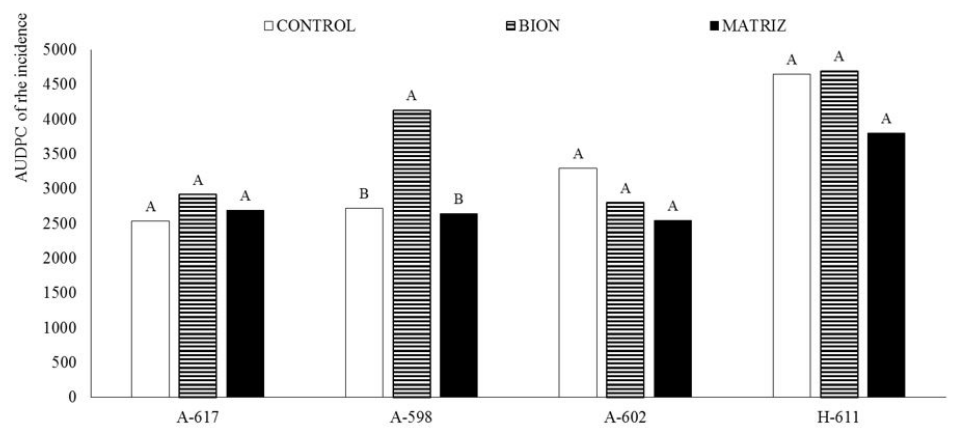

Figure 1. Means of area under the disease progress curve (AUDPC) of the incidence of leaves with black spot lesions and signs of hyperparasites: (A) estimated for isolates within each product (Control, Bion ${ }^{\circledR}$ and $\mathrm{Matriz}^{\circledR}$ ); and (B) estimated for products within each isolate (A-617, A-598, A-602 and H-611). Means followed by the same letter do not differ by Tukey test $(\mathrm{p}<0.05)$. Coefficient of variation equal to 21.16 . 
out after analyzing the severity of lesions of black spot hyperparasited, presenting the highest value of severity (Figure 2A). The results allow showing the fungus $H$. pulvinata (H-611 isolate) as the most promising and able to be used together with different alternative products, as it presented toxicological classification compatible with most of the alternative products, except Hortifos ${ }^{\circledR}$ (Table 2), besides presenting the highest means of colonization of black spot lesions. Another option to be applied in conjunction with the products testes would be the A-598 isolate, which presented the same H-611 means for both incidence and severity in Bion ${ }^{\circledR}$ and Matriz ${ }^{\circledR}$ products (Figures 1A, 2A).

The applications of the products did not interfere with reducing the mean of incidence of leaves with lesions of black spot hyperparasited by the different isolates (Figure 1B). By analyzing the means of the products in the isolates, there was a significant difference of product only in the A-598 isolate, being $\mathrm{Bion}^{\circledR}$ the one that presented the highest mean (Figure 1B). In the mean tests of the products to the severity of black spot lesions in leaves with signs of hyperparasites, there were not significant differences between the treatments; although the fungi applied together with Bion ${ }^{\circledR}$ have presented the highest means, they were not statistically different (Figure 2A, B). The findings of this research confirm the results of the tests in vitro, showing the compatibility to use the products Matriz ${ }^{\circledR}$ and Bion ${ }^{\circledR}$ together with the hyperparasitic fungi.

The Matriz ${ }^{\circledR}$ product is an organomineral fertilizer, which, besides improving the nutritional state of the plants, the nutrients can work as cofactors of enzymes that participate in the defence metabolism of the plants. Pratissoli et al. (2007), testing a product similar to Matriz ${ }^{\circledR}$,

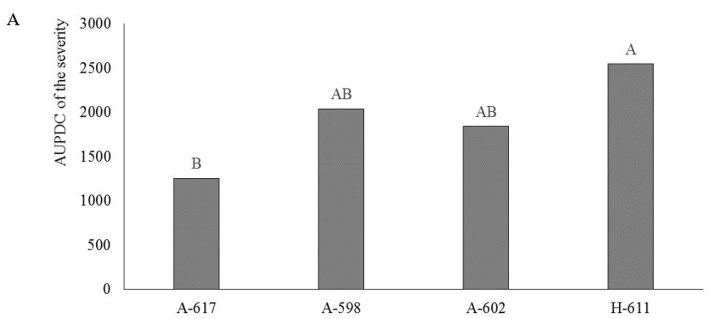

B

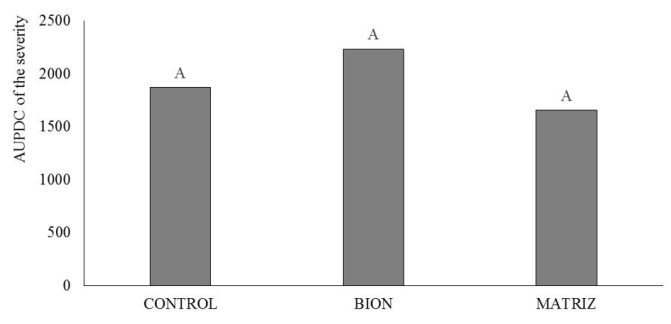

Figure 2. Means of area under the disease progress curve (AUDPC) of the severity of black spot lesions in leaves with signs of hyperparasites: (A) estimated for isolates based on the average of the products (Control, Bion ${ }^{\circledR}$ and Matriz $^{\circledR}$ ); and (B) estimated for products based on the mean of the isolates (A-617, A-598, A-602 and H-611). Means followed by the same letter do not differ by Tukey test $(p<0.05)$. Coefficient of variation equal to 25.20. and also considered an organomineral fertilizer, noticed that it reduced the incidence and severity of the papaya black spot. Besides being a product that can induce the defence mechanism in the plant, it did not interfere in the biological parameters of the hyperparasitic isolates (Table 2). Moreover, as it contains, in its formula, the same essential elements to the vital processes of fungi, and is in favorable concentrations, maybe that was the reason it did not influence on the biological index of the isolates tested. The product Bion ${ }^{\circledR}$, made from acibenzolar-S-methyl, has been cited as an effective resistance inductor, protecting plant systematically against a wide range of diseases caused by fungi and bacteria. Some authors tested the effect of Bion ${ }^{\circledR}$ on growth and sporulation of different fungi and concluded that there was not any alteration in the germination and mycelial growth (Galdeano et al., 2010; Bertoncelli et al., 2015).

On the other hand, experiments carried out in vitro showed that the Bion ${ }^{\circledR}$ and its metabolites, in high concentrations, significantly affected the development of the fungi (Soares et al., 2008). Nevertheless, the dosage used in this experiment was not enough to interfere in the biological parameters of the fungus in vitro, becoming, then, compatible with the product. Thus, it is expected that this product should be used together with the hyperparasites tested, once it did not interfere in the biological parameters (Table 2), as well as in its action in the greenhouse (Supplementary Material; Figure S1).

\section{Conclusion}

The fungus $H$. pulvinata $\mathrm{H}-611$ was the isolate that stood out as being compatible with most of the products used, and also the one that most colonized black spot lesions when inoculated with Bion ${ }^{\circledR}$ and Matriz ${ }^{\circledR}$.

The Bion ${ }^{\circledR}$ and Matriz ${ }^{\circledR}$ products can be used together with Acremonium spp. and $H$. pulvinata to control the papaya black spot, as these products did not have a toxic effect on the hyperparasitic fungi.

\section{Acknowledgements}

The authors thank the Darcy Ribeiro North Fluminense State University - UENF and National Council for Scientific and Technological Development - CNPq, for financial support.

\section{References}

ANHALT, F.A., AZEVEDO, J.L., SUGAYAMA, R.L., SPECHT, A. and BARROS, N.M., 2010. Potential of Metarhizium anisopliae (Metsch.) Sorokin (Ascomycetes, hypocreales) in the control of Bonagota salubricola (Meyrick) (Lepidoptera, Tortricidae) and its compatibility with chemical insecticides. Brazilian Journal of Biology $=$ Revista Brasileira de Biologia, vol. 70, no. 4, pp. 931-936. http://dx.doi.org/10.1590/S1519-69842010000500003. PMid:21180896.

BALDRIAN, P., 2003. Interactions of heavy metals with whitehot fungi. Enzyme and Microbial Technology, vol. 32, no. 1, pp. 78-91. http://dx.doi.org/10.1016/S0141-0229(02)00245-4. 
BARGUIL, B.M., RESENDE, M.L.V., RESENDE, R.S., BESERRA JÚNIOR, J.E.A. and SALGADO, S.M.L., 2005. Effect of extracts from citric biomass, rusted coffee leaves and coffee berry husks on Phoma costarricencis of coffee plants. Fitopatologia Brasileira, vol. 30, no. 5, pp. 535-537. http://dx.doi.org/10.1590/S010041582005000500014

BARRETO, L.F., SAVAN, P.A.L., LIMA, L.L. and LODO, B.N., 2011. Avaliação de fungicidas no controle de Asperisporium caricae na cultura do mamoeiro. Revista Brasileira de Fruticultura, vol. 33, no. spe1, pp. 399-403. http://dx.doi.org/10.1590/S010029452011000500051

BERGAMIN FILHO, A., 2008. Controle químico versus sustentabilidade na agricultura: o exemplo do huanglongbing dos citros. In: L. ZAMBOLIM, M.C. PICANÇO, A.A. SILVA, L.R. FERREIRA, F.A. FERREIRA and W.C. JESUS JUNIOR, eds. Produtos fitossanitários (fungicidas, inseticidas, acaricidas e herbicidas). Viçosa: UFV/DFP, pp. 1-26.

BERTONCELLI, D.J., MAZARO, S.M., ROCHA, R.C.D.S., POSSENTI, J.C. and WAGNER JÚNIOR, A., 2015. AcibenzolarS-metil na indução de resistência de tomateiro e controle de Rhizoctonia solani kuhn in vitro. Brazilian Journal of Applied Technology for Agricultural Science, vol. 8, no. 2, pp. 43-50. http://dx.doi.org/10.5935/PAeT.V8.N2.05.

BLUM, L.E.B., AMARANTE, C.V.T., DEZANET, A., LIMA, E.B., HACK NETO, P., ÁVILA, R.D. and SIEGA, V., 2007. Fosfitos aplicados em pós-colheita reduzem o mofo-azul em maçãs 'Fuji' e 'Gala'. Revista Brasileira de Fruticultura, vol. 29, no. 2, pp. 265-268. http://dx.doi.org/10.1590/S0100-29452007000200015.

CAMPBELL, C.L. and MADDEN, L.V., 1990. Introduction to plant disease epidemiology. New York: John Wiley \& Sons. 532 p.

COSTA, J.C.B., RESENDE, M.L.V., RIBEIRO JÚNIOR, P.M., CAMILO, F.R., MONTEIRO, A.C.A. and PEREIRA, R.B., 2010. Indução de resistência em mudas de cacaueiro contra Moniliophthora perniciosa por produto à base de mananoligossacarídeo fosforilado. Tropical Plant Pathology, vol. 35, no. 5, pp. 285-294. http:// dx.doi.org/10.1590/S1982-56762010000500003.

CRUZ, C.D., 2013. GENES - a software package for analysis in experimental statistics and quantitative genetics. Acta Scientiarum, vol. 35, no. 3, pp. 271-276. http://dx.doi.org/10.4025/actasciagron. v35i3.21251.

CRUZ, S.M.C., RODRIGUES, A.A.C., COELHO, R.S.B. and SARDINHA, D., 2011. Ação indutora de produtos abióticos na resistência de tomateiro e efeito sobre o crescimento micelial de Fusarium oxysporum f. sp. lycopersici. Idesia, vol. 29, no. 2, pp. 111-118. http://dx.doi.org/10.4067/S0718-34292011000200015.

GALDEANO, D.M., GUZZO, S.D., PATRICIO, F.R.A. and HARAKAVA, R., 2010. Proteção do cafeeiro contra cercosporiose por acibenzolar-S-metil e proteína harpina. Pesquisa Agropecuária Brasileira, vol. 45, no. 7, pp. 686-692. http://dx.doi.org/10.1590/ S0100-204X2010000700008

GHINI, R. and KIMATI, H., 2000. Resistência de fungos a fungicidas. 1. ed. Jaguariúna: Embrapa Meio Ambiente, 78 p.

GOMES, R.S.S., DEMARTELAERE, A.C.F., NASCIMENTO, L.C., MACIEL, W.O. and WANDERLEY, D.B.N.S., 2016. Bioatividade de indutores de resistência no manejo da antracnose da goiabeira (Psidiumguajava L.). Summa Phytopathologica, vol. 42, no. 2, pp. 149-154. http://dx.doi.org/10.1590/0100-5405/2103.

KING, M., REEVE, W., VAN DER HOEK, M.B., WILLIAMS, N., MCCOMB, J., O’Brien, P.A. and HARDY, G.E.S.J., 2010.
Defining the phophite-regulated transcriptome of the plant pathogen Phytophthoracinnamomi. Molecular Genetics and Genomics, vol. 284, no. 6, pp. 425-435. http://dx.doi.org/10.1007/s00438-0100579-7. PMid:20882389.

LIU, Z.Y., MILNER, R.J., MCRAE, C.F. and LUTTON, G.G., 1993. The use of Dodine in selective media for the isolation of Metarhizium spp. from soil. Journal of Invertebrate Pathology, vol. 62, no. 3, pp. 248-251. http://dx.doi.org/10.1006/jipa.1993.1107.

MARTELLETO, L.A.P., RIBEIRO, R.L.D., CARMO, M.G.F., SUDO-MARTELLETO, M. and GOES, A., 2009. Incidência da varíola, causada por Asperisporium caricae, em folhas de mamoeiros submetidos ao manejo orgânico em diferentes ambientes de cultivo. Summa Phytopathologica, vol. 35, no. 4, pp. 288-292. http://dx.doi.org/10.1590/S0100-54052009000400006.

MOTOYAMA, M.M., SCHWAN-ESTRADA, K.R.F., STANGARLIN, J.R., FIORI-TUTIDA, A.C.G. and SCAPIM, C.A., 2003. Indução de fitoalexinas em soja e em sorgo e efeito fungitóxico de extratos cítricos sobre Colletotrichum lagenarium e Fusarium semitectum. Acta Scientiarum. Agronomy, vol. 25, no. 2, pp. 491-496. http:// dx.doi.org/10.4025/actasciagron.v25i2.2062.

NOJOSA, G.B.A., RESENDE, M.L.V., BARGUIL, B.M., MORAES, S.R.G. and VILAS BOAS, C.H., 2009. Efeito de indutores de resistência em cafeeiro contra a mancha de Phoma. Summa Phytopathologica, vol. 35, no. 1, pp. 60-62. http://dx.doi. org/10.1590/S0100-54052009000100011.

OLIVEIRA, A.A.R. and NISHIJIMA, W., 2014. Induction of resistance to papaya black spot elicited by acibenzolar-S-methyl. Plant Pathology Journal, vol. 13, no. 2, pp. 120-124. http://dx.doi. org/10.3923/ppj.2014.120.124.

PRATISSOLI, D., DIAS DE ALMEIDA, G., JESUS JÚNIOR, W.C., VICENTINI, V.B., MATHIAS HOLTZ, A. and GORONCI COCHETO, J., 2007. Fertilizante organomineral e argila silicatada como indutores de resistência à varíola do mamoeiro. Idesia, vol. 25 , no. 2 , pp. 63-67. http://dx.doi.org/10.4067/S071834292007000200008

ROSSI-ZALAF, L.S., ALVES, S.B., LOPES, R.B., SILVEIRA NETO, S. and TANZINI, M.R., 2008. Interação de microrganismos com outros agentes de controle de pragas e doenças. In: S.B. ALVES and R.B. LOPES, eds. Controle microbiano de pragas na América Latina: avanços e desafios. Piracicaba: FEALQ, pp. 270-302.

SANTOS, M.C. and BARRETO, M., 2003. Estudos epidemiológicos da varíola do mamoeiro em cultivares submetidas a tratamentos com fungicidas. Summa Phytopathologica, vol. 29, no. 2, pp. 141-146.

SANTOS, P.H.D., SILVEIRA, S.F., VIVAS, M., CARVALHO, B.M. and PEREIRA, M.G., 2017. Alternative control to black spot disease in papaya genotypes. Summa Phytopathologica, vol. 43, no. 1, pp. 60-62. http://dx.doi.org/10.1590/0100-5405/2208.

SOARES, A.C.F., PEREZ, J.O., SOUSA, C.S., GARRIDO M. S. and ALMEIDA, N.S., 2008. Eficiência do acibenzolar-S-metil na proteção de plantas de inhame à Curvularia eragrostides. Revista Caatinga, vol. 21, no. 1, pp. 147-151.

SUZUKI, M.S., ZAMBOLIM, L. and LIBERATO, J.R., 2007. Progresso de doenças fúngicas e correlação com variáveis climáticas em mamoeiro. Summa Phytopathologica, vol. 33, no. 2, pp. 167-177. http://dx.doi.org/10.1590/S0100-54052007000200011.

VENTURA, J.A. and REZENDE, J.A.M., 2016. Doenças do mamoeiro. In: L. AMORIM, J.A.M. REZENDE, A. BERGAMIM FILHO and L.F.A. CAMARGO, eds. Manual de fitopatologia: 
doenças das plantas cultivadas. 5. ed. São Paulo: Agronômica Ceres, pp. 497-510.

VIVAS, J.M.S., SILVEIRA, S.F., SANTOS, P.H.D., CARVALHO, B.M., POLTRONIERI, T.P.S., JORGE, T.S., SANTOS, J.S., KUROSAWA, R.N.F. and MORAES, R., 2018. Antagonism of fungi with biocontrol potential of papaya black spot caused by Asperisporium caricae. Australian Journal of Crop Science, vol. 12, no. 4, pp. 827-833. http://dx.doi.org/10.21475/ajcs.18.12.05. PNE1073.

VIVAS, J.M.S., SILVEIRA, S.F., SANTOS, P.H.D., PINHO, D.B. and PEREIRA, O.L., 2017. Selection of fungi with biocontrol potential against the black spot disease of papaya. Pesquisa
Agropecuária Tropical, vol. 47, no. 4, pp. 369-376. http://dx.doi. org/10.1590/1983-40632017v4749178

VIVAS, J.M.S., VIVAS, M. and SILVEIRA, S.F., 2015. Efeito da temperatura sobre o crescimento e esporulação in vitro de fungos hiperparasitas de Asperisporium caricae. Pesquisa Agropecuária Tropical, vol. 45, no. 1, pp. 73-81. http://dx.doi.org/10.1590/1983$40632015 \mathrm{v} 4529774$

VIVAS, M., SILVEIRA, S.F., TERRA, C.E.P.S. and PEREIRA, M.G., 2011. Testers for combining ability and selection of papaya hybrids resistant to fungal diseases. Crop Breeding and Applied Biotechnology, vol. 11, no. 1, pp. 36-42. http://dx.doi.org/10.1590/ S1984-70332011000100005. 


\section{Supplementary Material}

Supplementary material accompanies this paper.

Figure S1. Papaya leaves showing typical symptoms of black spot and hyperparasitic fungi: A) Signs of black spot on the control plant; B) Signs of hyperparasite Acremonium spp. in black spot lesions; C) Signs of hyperparasite Acremonium spp. in black spot lesions on plants with the Bion ${ }^{\circledR}$ product; D) Signs of Hansfordia pulvinata in black spot lesions; and, E) Signs of H. pulvinata in plant black spot lesionswith the Bion ${ }^{\circledR}$ product.

This material is available as part of the online article from http://www.scielo.br/bjb 